\title{
PERFORMA ITIK LOKAL (Anas $S p$ ) YANG DIBERI TEPUNG DAUN KELOR (Moringa oleifera) PADA PAKAN DENGAN SISTEM PEMELIHARAAN INTENSIF
}

\author{
Daryatmo $^{1}$, M. Rachman Hakim ${ }^{1}$ \\ ${ }^{1)}$ Fakultas Peternakan Universitas Hasanuddin \\ email : daryatmo@unhas.ac.id
}

\begin{abstract}
ABSTRAK
Penelitian dilakukan untuk menguji pengaruh pakan yang diberi tepung daun kelor (Moringa oliefera) terhadap performa itik lokal (Anas Sp). Sebanyak 80 ekor itik lokal umur sehari dipelihara hingga umur 10 minggu berdasarkan rancangan acak lengkap dengan 4 perlakuan dan 4 ulangan. Perlakuan berupa penambahan tepung daun kelor pada pakan basal dengan level yang berbeda (masing-masing $0 \%, 1 \%, 2 \%$, dan $3 \%$ ). Parameter yang diamati yaitu berat badan akhir, pertambahan bobot badan, konsumsi pakan, konversi pakan, dan mortalitas. Penimbangan bobot badan dan sisa pakan dilakukan setiap minggu selama masa pemeliharaan. Hasil menunjukkan pakan yang diberi tepung daun kelor tidak memberikan pengaruh yang nyata terhadap performa itik lokal pada semua parameter yang diamati $(\mathrm{P}>0,05)$.
\end{abstract}

Kata Kunci : Performa Itik Lokal, Tepung Daun Kelor

\begin{abstract}
The study was conducted to examine the effect of feed by moringa leaf flour (Moringa oliefera) on the performance of local ducks (Anas $S p$ ). A total of 80 day old ducks keep until the age of 10 weeks, and arranged as a completely randomized design with 4 treatments and 4 replications. The treatments were the addition of turmeric powder on the basal feed with different levels (respectively 0\%,1\%,2\% and 3\%). The parameters observed final body weight, were weight gain, feed intake, , feed conversion, and mortality. Weighing body weight and feed residue is done every weeks during the maintenance period. The results showed that the feed given moringa leaf flour does not have a significant influence on the performance of local ducks in all parameters were observed $(\mathrm{P}>0.05)$.
\end{abstract}

Key Words : Local Duck Performance, Moringa Leaf Flour

\section{PENDAHULUAN}

Kebutuhan masyarakat akan produk peternakan semakin meningkat. Saat ini, industri peternakan yang ada di Indonesia menghasilkan sekitar 2.925.210 ton daging, dan pemasok daging terbesar yaitu ayam sebesar 66 $\%$, daging sapi $17 \%$, itik hanya mampu menghasilkan 38.840 ton atau hanya sebesar $1,32 \%$ dari total produksi daging Indonesia (Ditjennak, 2015).
Dari data tersebut menunjukkan bahwa ternak itik merupakan salah satu jenis unggas yang potensial untuk dikembangkan karena dapat membantu memenuhi kebutuhan telur dan daging masyarakat. Walaupun sumbangan ternak itik masih relatif kecil, tetapi memiliki potensi untuk dikembangkan dan hal ini ditunjukkan oleh peluang pasar yang cukup besar.

Untuk memenuhi permintaan daging itik yang semakin meningkat 
maka diperlukan upaya untuk meningkatkan performa ternak itik yang sekarang ini masih tergolong sangat rendah. Umumnya pemeliharaan itik merupakan masih bersifat tradisional sehingga produktifitasnya masih rendah. Perubahan pola pemeliharaan ke sistem intensif dapat meningkatkan performa ternak itik. Dengan sistem pemeliharaan intensif, kebutuhan nutrisi ternak itik dapat terpenuhi dengan baik.

Pada sistem pemeliharaan secara intensif mengharuskan peternak untuk menyediakan pakan yang memiliki unsur gizi yang cukup untuk kebutuhan ternak itik. Penggunaan pakan dari pabrik masih jarang diberikan karena ternak itik memiliki konversi pakan yang masih tinggi sehingga mengakibatkan biaya pakan yang mahal. Penggunaan bahan alami yang mengandung kandungan nutrisi yang tinggi diperlukan untuk meningkatkan performa ternak itik.

Kelor (Moringa oleifera) merupakan salah satu tumbuhan perdu yang ketersediaannya di Indonesia cukup banyak dan memungkinkan digunakan sebagai bahan pakan. Kandungan bahan aktif yang terdapat dalam daun kelor yang berpotensi sebagai antioksidan, antibakteria, imunostimulan dan beberapa vitamin terlarut dalam air misalnya vit.C, dapat memberikan kontribusi dalam meningkatkan performa ternak itik lokal. Selain itu daun kelor memiliki kandungan protein yang cukup tinggi. Suplementasi kelor, selain meningkatkan performa, juga memperbaiki karakteristik kimia darah, dan meningkatkan respon imun tubuh terutama dengan menurunkan kandungan asam urat, trigliserida, dan rasio albumin/globulin pada serum ayam pedaging (Du et. al., 2007).

Penggunaan daun kelor pada ternak unggas sudah banyak dilakukan tetapi masih terbatas pada ternak ayam pedaging dan puyuh sedangkan terhadap ternak itik belum pernah dilakukan. Sehingga penelitian ini di harapkan dapat mengetahui pengaruh penggunaan daun kelor sebagaia sumber pakan alami pada ternak itik. Selain itu penelitian ini dapat menjadi sumber informasi awal dalam pengembangan industri peternakan itik lokal.

\section{MATERI DAN METODE}

Penelitian ini dilaksanakan di Laboratorium Ternak Unggas, Departemen Produksi Ternak, Fakultas Peternakan, Universitas Hasanuddin, Makassar. Materi yang digunakan dalam penelitian ini adalah itik lokal sebanyak 60 ekor dengan jenis kelamin campuran (unsexed), tepung daun kelor, dan air minum. Pakan yang digunakan terdiri dari pakan starter pedaging, konsentrat, jagung kuning, dedak dan premix. Penelitian dilakukan secara eksperimen menggunakan Rancangan Acak Lengkap (RAL) dengan 4 perlakuan dan 3 ulangan. Tiap ulangan terdiri dari 5 ekor itik sebagai subulangan. Perlakuan yang diterapkan yaitu pemberian 4 jenis pakan yang berbeda yaitu :

$$
\begin{aligned}
\mathrm{K} 0= & \text { Pakan basal }+0 \% \text { tepung } \\
& \text { daun kelor } \\
\mathrm{K} 1= & \text { Pakan basal }+1 \% \text { tepung daun } \\
& \text { kelor } \\
\mathrm{K} 2= & \text { Pakan basal }+2 \% \text { tepung daun } \\
& \text { kelor } \\
\mathrm{K} 3= & \text { Pakan basal }+3 \% \text { tepung daun } \\
& \text { kelor }
\end{aligned}
$$

Perlakuan pemberian tepung daun kelor dilakukan melalui pakan dan dimulai pada umur sehari hingga akhir periode pemeliharaan yaitu pada umur 10 Minggu dengan level penambahan sesuai perlakuan. 


\section{Prosedur Penelitian}

a. Kandang unit percobaan

Kandang yang digunakan adalah kandang postal. Di dalam kandang, dibuat petak untuk setiap unit percobaan menggunakan sekat bambu yang berukuran panjang $150 \mathrm{~cm}$, lebar 100 $\mathrm{cm}$, dan tinggi $50 \mathrm{~cm}$ dan alas kandang menggunakan litter dari serbuk gergaji.

b. Pembuatan tepung daun kelor

Daun kelor yang digunakan berasal dari tanaman kelor lokal yang sehat. Daun tanaman kelor segar dikumpulkan dan dipisahkan dari tangkai tanaman. Pengeringan pada suhu ruang dilakukan selama 7 hari tanpa sinar matahari hingga kadar air mencapai dibawah $20 \%$. Penggilingan hingga halus dilakukan, dan hasilnya berupa tepung ditimbang dan dicampurkan bersama dengan bahan pakan lain sesuai dengan perlakuan

Tabel 1. Kandungan Nutrisi Tepung Daun Kelor Berdasarkan (\%BK)

\begin{tabular}{lc}
\hline Komposisi Nutrisi $(\%)$ & Kandungan \\
\hline Protein kasar & 30.3 \\
Energi Metabolisme & 1390 \\
Lemak kasar & 6.13 \\
Serat kasar & 12.48 \\
$\mathrm{Abu}$ & 12.6 \\
$\mathrm{Ca}$ & 2.66 \\
$\mathrm{P}$ & 0.95 \\
\hline
\end{tabular}

Sumber : Laboratorium Kimia dan Makanan Ternak Universitas Hasanuddin, Makassar.

\section{c. Pakan}

Pakan yang digunakan berbentuk crumble untuk itik umur 1-14 hari sedangkan pakan berbentuk mash digunakan untuk itik umur 15 - 70 hari Pakan diberikan dua kali dalam sehari dan ditimbang dengan jumlah pemberian.

Tabel 2. Kandungan Nutrisi Pakan Starter Periode Umur -14 Hari Pemeliharaan

\begin{tabular}{lc}
\hline Komposisi Nutrisi (\%) & Starter (Crumble) \\
\hline Protein kasar & $22-23$ \\
Energi Metabolisme & 2900 \\
Lemak kasar & 6 \\
Serat kasar & $3-4$ \\
Abu & 50 \\
$\mathrm{Ca}$ & 5,5 \\
$\mathrm{P}$ & 1,5 \\
\hline
\end{tabular}

Sumber : Analisis Laboratorium Produsen 
Tabel 3. Komposisi Pakan Finisher Periode Umur 15 - 70 Hari Pemeliharaan

\begin{tabular}{lcccc}
\hline Komposisi Nutrisi (\%) & \multicolumn{4}{c}{ Perlakuan } \\
\cline { 2 - 5 } & K0 & K1 & K2 & K3 \\
\hline Konsentrat Finisher & 30 & 29 & 28 & 27 \\
Jagung & 50 & 50 & 50 & 50 \\
Dedak Halus & 20 & 20 & 20 & 20 \\
Tepung Daun Kelor & - & 1 & 2 & 3 \\
\hline Jumlah & 100 & 100 & 100 & 100 \\
\hline Kandungan Nutrisi $*$ & & & & \\
Protein kasar & 18,77 & 18,70 & 18,62 & 18,54 \\
Energi Metabolisme & 2855 & 2869,00 & 2858,00 & 2847,00 \\
Lemak kasar & 6,05 & 6,02 & 6,00 & 5,97 \\
Serat kasar & 6,885 & 6,79 & 6,70 & 6,60 \\
Abu & 7,725 & 7,58 & 7,44 & 7,29 \\
\hline
\end{tabular}

*Berdasarkan hasil perhitungan

\section{d. Pemeliharaan ternak}

Pemeliharaan ternak dilakukan selama 10 minggu. itik ditempatkan pada kandang unit percobaan yang menggunakan lampu pijar sebagai pemanas pengganti indukan. Pada umur 15 - 70 hari, lampu pijar dinaikkan untuk menyesuaikan suhu dan sebagai sumber cahaya. Petak kandang unit percobaan diacak setiap unit percobaan dengan masing-masing petak diisi 5 ekor itik. Lama pencahayaan selama penelitian adalah 24 jam.

\section{Parameter yang diukur}

\section{a. Pertambahan Bobot Badan}

Pertambahan bobot badan yaitu selisih bobot hidup pada saat akhir tertentu dengan bobot hidup semula (Purba, 2011)

\section{b. Konsumsi Pakan}

Menurut Purba (2011) konsumsi pakan merupakan banyaknya pakan yang diberikan dikurangi sisa pakan atau angka yang menunjukkan rata-rata jumlah pakan yang dapat dikonsumsi seekor ternak dengan periode pemeliharaan.

\section{c. Konversi pakan}

Konversi pakan adalah pembagian antara jumlah pakan yang dikonsumsi pada minggu tertentu dengan pertambahan bobot hidup yang didapat pada minggu itu pula (Purba, 2011).

\section{d. Mortalitas}

Mortalitas merupakan persentasi jumlah ternak yang mati. Angka mortalitas dapat diperoleh dengan cara menghitung total ternak yang mati selama penelitian dibagi dengan jumlah ternak awal dikalikan $100 \%$ (Purba, 2011)

\section{Analisis Data}

Data yang dperoleh diolah dengan menggunakan sidik ragam sesuai Rancangan Acak Lengkap (RAL). Perlakuan yang berbeda nyata terhadap perubah yang diukur maka dilanjutkan dengan Uji Beda Nyata Terkecil (BNT) (Gaspersz,1991).

\section{HASIL DAN PEMBAHASAN}

Adapun performa itik lokal yang diberi tepung daun kelor (Moringa oliefera) dengan level berbeda hingga umur 10 minggu dapat dilihat pada Tabel 4. 
Tabel 4. Performa Itik Lokal yang Diberi Tepung Daun Kelor(Moringa oliefera)

\begin{tabular}{lcccc}
\hline Parameter & \multicolumn{4}{c}{ Perlakuan } \\
\hline \multicolumn{1}{c}{ K0 } & K1 & K2 & K3 \\
\hline $\begin{array}{l}\text { Berat Badan Akhir } \\
(\mathrm{g})\end{array}$ & $1220,26 \pm 73,43$ & $1245,61 \pm 69,20$ & $1253,84 \pm 68,63$ & $1264,85 \pm 57,41$ \\
\hline $\begin{array}{l}\text { PBB } \\
\text { (g/ekor/minggu) }\end{array}$ & $114,53 \pm 8,31$ & $117,10 \pm 7,88$ & $117,88 \pm 9,54$ & $118,98 \pm 5,86$ \\
\hline $\begin{array}{l}\text { Konsumsi Pakan } \\
\text { (g/ekor) }\end{array}$ & $6479,22 \pm 340,52$ & $6488,76 \pm 290,93$ & $6510,52 \pm 316,25$ & $6531,21 \pm 283,75$ \\
\hline Konversi Pakan & $5,31 \pm 0,51$ & $5,21 \pm 0,54$ & $5,19 \pm 0,45$ & $5,16 \pm 0,49$ \\
\hline Mortalitas $(\%)$ & 0 & 0 & 0 & 0 \\
\hline
\end{tabular}

\section{A. Berat Badan Akhir}

Berat badan akhir pada penelitian ini dicantumkan pada Tabel 4. Rata-rata berat badan akhir pada umur 10 minggu berkisar antara 1220,26 gram (K0) - 1264,85gram (K3). Perlakuan penambahan tepung daun kelor hingga 3\% dalam pakan tidak menyebabkan adanya perbedaan nyata pada pencapaian berat badan ternak itik. Kelompok itik yang diberi tepung daun kelor pada level 1, 2 dan $3 \%$ dalam pakan secara statistik tidak berbeda nyata $(\mathrm{P}>0,05)$ dengan itik pada kelompok kontrol. Hal ini kemungkinan disebabkan jumlah konsumsi dan kandungan nutrisi dalam pakan yang diberikan hampir sama. Selain itu pemberian tepung daun kelor tidak memberikan efek negatif terhadap pencapaian berat badan akhir dari ternak itik perlakuan.

Hasil penelitian ini masih lebih rendah dari beberapa penelitian lain. Prasetyo dan Susanti (2007), melaporkan bahwa berat badan itik Mojosari pada umur 8 Minggu rata-rata 1250,6 gram/ekor. Selain itu Purba dan Ketaren (2011), juga melaporkan berat badan akhir pada ternak itik MA pada umur 8 minggu rata-rata 1425,72 gram/ekor. Perbedaan ini kemungkinan besar disebabkan oleh perbedaan genetik/bibit, komposisi maupun nutrien yang terkandung dalam pakan.

\section{B. Pertambahan Berat Badan}

Tingkat pertumbuhan ternak itik dapat dilihat berdasarkan pertambahan berat badan selama pemeliharaan berlangsung. Salah satu tujuan pemeliharaan ternak itik yang baik ialah pencapaian berat badan yang sesuai dengan standar pemeliharaan berdasarkan tingkatan umur. Berdasarkan data Tabel 4, rata-rata pertambahan berat badan ternak itik yang diberikan tepung daun kelor pada penelitian ini berkisar antara 114,53 $118,98 \mathrm{gram} / \mathrm{minggu}$. Berdasarkan hasil analisis ragam, perlakuan penambahan tepung daun kelor hingga 3\% tidak memberikan pengaruh yang nyata $(\mathrm{P}>0,05)$ terhadap pertambahan berat badan ternak itik. Hal ini memberikan indikasi bahwa respon ternak itik terhadap perlakuan baik dengan penambahan tepung daun kelor maupun kontrol cenderung sama. Purba dan Ketaren (2011), penambahan antioksidan dalam pakan tidak memberikan pengaruh nyata terhadap pertambahan berat badan ternak itik. Selain itu Sjofjan (2008), melaporkan penambahan tepung daun kelor pada ayam broiler tidak memberikan pengaruh yang nyata terhadap pertambahan berat badan. Hal ini kemungkinan disebabkan karena kandungan pakan terutama energi dan protein yang diberikan hampir sama sehingga menghasilkan pertambahan berat badan yang relatif sama. 


\section{Konsumsi Pakan}

Tingkat konsumsi pakan ternak itik (Tabel 4) yang diamati selama 10 minggu berdasarkan hasil analisis ragam tidak menunjukkan adanya perbedaan nyata $(\mathrm{P}>0,05)$ diantara perlakuan, baik dengan kontrol maupun perlakuan dengan level pemberian yang berbeda. Rataan konsumsi kumulatif itik selama 10 minggu berkisar antara 6479,22 g/ekor (K0) hingga 6531,21 g/ekor (K3).

Hasil ini sejalan dengan Sjofjan (2008), yang melakukan penelitian tentang pengaruh pemberian tepung daun kelor dalam pakan broiler bahwa tidak ada perbedaan yang nyata terhadap konsumsi pakan yang diberi tepung daun kelor dengan pakan yang tidak diberi tepung daun kelor. Hal ini menunjukkan bahwa bahwa tepung daun kelor tidak mempengaruhi tingkat konsumsi pakan. Hal yang berbeda dikemukakan oleh oleh Ayssiwede dkk. (2011) penggunaan tepung daun kelor pada ayam lokal yang berada dalam fase pertumbuhan di Senegal menunjukkan adanya penurunan tingkat konsumsi pakan setelah diberi tepung daun kelor dalam pakan. Penurunan tersebut lebih banyak diarahkan pada palatabilitas bahan baku pakan yang bersumber dari daun kelor oleh ayam lokal yang lebih rendah dibanding bahan baku pakan lain. Palatabilitas yang rendah juga dapat dihubungkan dengan kandungan antinutrisi seperti tannin yang tinggi dari daun kelor yang memiliki kemampuan untuk mengikat protein pakan dan enzim-enzim yang dibutuhkan dalam pencernaan membentuk senyawa kompleks yang tidak dapat dicerna (Soetan dan Oyewole, 2009).

\section{Konversi Pakan (FCR)}

Konversi pakan

(FCR)

merupakan salah satu aspek yang perlu diperhatikan dalam setiap pemeliharaan ternak untuk melihat seberapa efisien pakan digunakan. Semakin kecil nilai $F C R$ menunjukkan semakin efisien panggunaan pakan yang diberikan. Hasil penelitian ini pada tabel 4. menunjukkan rata-rata nilai FCR antara 5,16 (K3) - 5,31 (K0). Berdasarkan analisis ragam menunjukkan hasil yang tidak berbeda nyata dengan perlakuan lain maupun kontrol sehingga ini menunjukkan baha penggunaan tepung daun kelor tidak memberikan pengaruh yang nyata terhadap konversi pakan.

Tidak adanya perbedaan pengaruh yang nyata ini disebabkan tingkat konsumsi dan berat badan akhir yang dicapai pada masing-masing perlakuan hampir sama. Angka konversi pakan dipengaruhi antara lain strain atau bangsa, mutu pakan, keadaan kandang dan jenis kelamin. Umumnya strain dengan genetik yang kurang baik,mutu pakan yang buruk, keadaan kandang yang kurang baikdan jenis kelamin betina akan menghasilkan konversi pakan yang lebih besar serta mengurangi nilai keefektifan penggunaan pakan (Rasyaf, 1995).

\section{E. Mortalitas}

Selama pemeliharaan itik yakni mulai dari umur sehari (DOD) hingga umur 10 minggu, pada penelitian ini tidak terdapat ternak itik yang mati baik pada kontrol maupun pada perlakuan. Hal ini menunjukkan bahwa ternak itik memiliki kemampuan yang baik dalam beradaptasi terhadap jenis pakan dan lingkungan yang ada. Selain itu ternak itik juga memiliki daya tahan yang baik terhadap serangan penyakit. 


\section{KESIMPULAN}

Penambahan tepung daun kelor dalam pakan hingga taraf $3 \%$ tidak memberikan pengaruh yang nyata terhadap performa ternak itik lokal yang dipelihara scara intensif yang meliputi berat badan akhir, pertambahan berat badan, konsumsi pakan, konversi pakan $(F C R)$ dan mortalitas.

\section{DAFTAR PUSTAKA}

Ayssiwede, S. B., A. Dieng, H. Bello, C. A. A. M. Chrysostome, M.B. Hane,A. Mankor, M. Dahouda,M. R. Houinato,J. L. Hornick, A. Missohou. 2011. Effects of Moringa oleifera (Lam.) leaves meal incorporation in diets on growth performances, carcass characteristics and economics results of growing indigenous Senegal chickens. Pak. J. Nutr., 10 (12): 1132-1145

Ditjennak. 2015. Statistik Peternakan dan Kesehatan Hewan. Direktoran Jendral Peternakan dan Kesehatan Hewan Kementrian Pertanian RI : Jakarta

Du, P.L., P.H. Li, R. Y. Yang, and J. C. Hsu. 2007. Effect of dietary supplementation of Moringa oleifera on growth performance, blood characteristics and immune response in broiler. J. Chinese Society Anim. Sci. 36(3): 135-146.

Gaspersz, 1991. Teknik Analisis dalam Penelitian Percobaan. Tarsito: Bandung
Prasetyo L.H. dan T. Susanti. 2007. Pendugaan parameter genetik bobot badan itik Alabio dan Mojosari pada periode starter. JITV 12(3): 212217.

Purba, M., P. Ketaren. 2011. Konsumsi dan konversi pakan itik lokal jantan umur delapan minggu dengan penambahan santoquin dan vitamin $\mathrm{E}$ dalam pakan. JITV, 16(4): 280-287

Rasyaf, M. 1995. Beternak Ayam Pedaging. Penebar Swadaya, Jakarta.

Sjofjan, O. 2008. Efek pengunaan tepung daun kelor (Moringa oleifera) dalam pakan terhadap penampilan produksi ayam pedaging. Prosiding Seminar Nasional Teknologi Peternakan dan Veteriner.p:649-656.

Soetan, K. O., and O. E. Oyewole. 2009. The need for adequate processing to reduce the antinutritional factors in plants used as human food and animal feeds:a review. African J. Food Sci., 3(9):223-232. 